\title{
Measuring school children's attitudes toward immigrants in Switzerland and Poland
}

\author{
Charlotte Clara Becker ${ }^{1 *}$ (D) Eldad Davidov ${ }^{2,3,4}$, Jan Cieciuch $^{3,5}$, René Algesheimer ${ }^{6}$ and Martin Kindschi ${ }^{7}$
}

\begin{abstract}
For decades, social scientists have been interested in studying individual attitudes toward ethnic minorities or immigrants and their development over time. Whereas these attitudes have been commonly studied among adults, little is known about children's and teenager's attitudes toward immigrant minorities. This gap might have been a result of a lack of standardized, cost-effective, and efficient large-scale survey measures tailored to young people. In the current study, we try to overcome this gap by introducing and validating a new, child-friendly, easily administrable picture-based survey measure of attitudes toward immigrants belonging to two ethnic minorities: blacks and Muslims.

For this purpose, we collected a panel dataset at three measurement time points in two countries, Switzerland and Poland, including 5332 school children and teenagers aged 8 to 19 years, divided into three age cohorts. We performed confirmatory factor analyses within and across the samples and found that the new picture-based measures were reliable and highly comparable across measurement time points, age cohorts, and country samples. The findings suggest that picture-based measures may be a promising tool to measure attitudes among children.
\end{abstract}

Keywords: Attitudes toward ethnic minorities, Measuring children's attitudes, Picture-based measures, Panel data, Cross-cultural data, Measurement equivalence, Multi-group confirmatory factor analysis

\section{Introduction}

\section{Rationale and structure}

In the last decade, the number of votes for right-leaning parties in newly elected parliaments has increased (Akkerman, de Lange, \& Rooduijn, 2016), and this rise has been accompanied by a shift of the political orientation of Europeans toward the far right and high levels of negative attitudes toward immigrants (Decker \& Brähler, 2018). Even politicians do not refrain from publicly proclaiming their negative sentiments toward certain ethnic and religious immigrant groups (Decker \& Brähler, 2018). These negative attitudes toward minorities have been a major topic of investigation among social scientists for several decades (Aydin, Krueger,
Frey, Kastenmüller, \& Fischer, 2014; Berry \& Kalin, 1995; Esses, Jackson, \& Armstrong, 1998; Powdermaker, 1944). Their studies examined the level, development, and possible sources of such attitudes among adult populations (Berthoff, 1951; Decker \& Brähler, 2018; Rustenbach, 2010; Savelkoul, Scheepers, van der Veld, \& Hagendoorn, 2012).

However, there has been little large-scale research on children's and teenager's attitudes toward ethnic and religious minorities. This lacuna is unfortunate because studying attitudes of societies' youngest members bears the opportunity to gain deeper insight into current sentiments toward minorities. After all, children's attitudes may foreshadow not only present but also future societal

\footnotetext{
* Correspondence: becker@wiso.uni-koeln.de

${ }^{1}$ Cologne Graduate School in Management, Economics and Social Sciences and Institute of Sociology and Social Psychology, University of Cologne,

Albertus-Magnus-Platz, 50923 Cologne, Germany

Full list of author information is available at the end of the article
}

(c) The Author(s). 2020 Open Access This article is licensed under a Creative Commons Attribution 4.0 International License, which permits use, sharing, adaptation, distribution and reproduction in any medium or format, as long as you give appropriate credit to the original author(s) and the source, provide a link to the Creative Commons licence, and indicate if changes were made. The images or other third party material in this article are included in the article's Creative Commons licence, unless indicated otherwise in a credit line to the material. If material is not included in the article's Creative Commons licence and your intended use is not permitted by statutory regulation or exceeds the permitted use, you will need to obtain permission directly from the copyright holder. To view a copy of this licence, visit http://creativecommons.org/licenses/by/4.0/. 
developments such as future levels of tolerance and prejudice. However, measuring attitudes particularly among children and young adolescents may be challenging, because it is unclear whether they understand survey questions in a similar way to adults and if their responses are equally reliable. Commonly used largescale survey data such as the European Social Survey (ESS; European Social Survey, 2018) or the International Social Survey Program (ISSP; ISSP Research Group, 2015) only cover information about attitudes of the adult population. Furthermore, standardized, cost-effective, and efficient survey measures tailored to young people and applicable to large samples have been lacking.

In the current study, we try to fill this gap by introducing and validating a new, child-friendly, easily administrable picture-based survey measure of attitudes toward immigrants that is applicable across many Western countries. For this purpose, we collected a panel dataset at three measurement time points in two countries, Switzerland and Poland. Our dataset includes 5332 school children and teenagers aged 8 to 19 years, divided into three age cohorts. For the validation, we performed confirmatory factor analyses within and across the samples and found that our proposed measures were reliable and highly comparable across measurement time points, age cohorts, and country samples.

We begin with a brief definition of attitudes and an overview of previous research assessing attitudes toward ethnic minorities in general, and among children in particular, listing challenges in measuring children's attitudes and possible considerations to overcome these challenges. In the following section, we propose an innovative, concrete, child-friendly, easily administrable picture-based tool, applicable in Western countries, for large sample sizes, to measure children's attitudes toward immigrants belonging to ethnic minority groups. Next, we describe our panel data collected using these measures and examine the validity and comparability of the measures across children of different age cohorts in two countries and over time.

\section{Previous work}

\section{Measuring adults' attitudes toward minorities}

Attitudes describe the evaluations of individual objects, persons, or situations (Eagly \& Chaiken, 1998; Krech, Crutchfield, \& Ballachey, 1962; Thurstone, 1931). For each new object arising, a new evaluation and hence attitude will be formed. While attitudes are not as stable as sociodemographic characteristics, personality traits, or values, they are likely to change over time as well as to vary across different life situations (Alwin \& Krosnick, 1991). An individual's attitude toward immigrants is thus his or her current personal assessment of immigrants.

The measurement of adults' attitudes toward ethnic minorities in surveys has commonly been performed using single or multiple questions tapping into various dimensions of such attitudes. Some of these questions have become popular and therefore have been integrated into national and international surveys, such as the ESS (European Social Survey, 2018), the ISSP (ISSP Research Group, 2015), or the German Social-Economic Panel (SOEP, Schupp et al., 2017). For example, the question asking whether respondents think that immigrants undermine the culture in their country has been used to measure symbolic threat due to immigrants (ISSP Research Group, 2015), and the question asking to what extent respondents would be bothered by a member of a certain ethnic group being their neighbor, boss, or son- 1 daughter-in-law has been used to measure social distance (De Graaf, Kalmijn, Kraaykamp, \& Monden, 2010; Hindriks, Verkuyten, \& Coenders, 2014). Some of these questions allow measuring attitudes toward specific ethnic groups, while others refer to ethnic minorities or immigrants in general (for a description of various multiple indicator scales used to measure attitudes toward immigrants, e.g., see the description of the immigration module in the ESS 2014/15 in Heath et al., 2016). Such measures allow a straightforward implementation in international surveys and the collection of large-scale, high quality, and comparable data (Davidov et al., 2015; Davidov, Cieciuch, \& Schmidt, 2018).

\section{Using survey questions to measure children's attitudes}

The main challenge in using surveys to measure children's attitudes is that children are at a lower, constantly changing stage of development of their cognitive skills compared to adults (Piaget, 1929, 1960; Piaget et al., 1928; Sutherland, 1992; see also Aboud, 2008). Thus, questions which may be easily answered by most adults may not be applicable for children and young adolescents, because they may be too abstract or complicated, or use a vocabulary which is beyond the scope of children's comprehension. Furthermore, children in comparison to adults are likely to have a harder time concentrating and paying attention over a longer period of time (Gómez-Pérez \& Ostrosky-Solís, 2006). These problems pose a threat to the validity and reliability of common survey questions to measure attitudes toward ethnic minorities among children.

Research has shown, however, that even young children are able to report attitudes and opinions as long as the method of data collection is designed in a childfriendly way (Eid \& Diener, 2006; La Greca, 1990). This could include using a simpler vocabulary that children are familiar with, keeping the questionnaire relatively 
short, or designing individual questions while having the young respondents' cognitive abilities in mind by, for example, using pictures. Pictures can help capture and maintain children's or young adolescents' attention (Harter \& Pike, 1984); they can facilitate the comprehension of accompanying texts (Donald, 1979; Fang, 1996; Pike, Barnes, \& Barron, 2010) and help young respondents build mental models of the content (Glenberg \& Langston, 1992). One example for a successful implementation of pictures in surveys is the Picture-Based Value Survey for Children (PBVS-C) measuring young children's abstract values (Döring, Blauensteiner, Aryus, Drögekamp, \& Bilsky, 2010), in which children are presented pictures rather than text to describe each value with the task to prioritize them. Working with pictures enhances the children's ability to understand the meaning of the value questions (Cieciuch, Döring, \& Harasimczuk, 2013; Döring et al., 2010).

\section{Measuring children's attitudes toward ethnic minorities in previous research}

Several researchers in the USA have examined attitudes of children toward whites and blacks (Baron \& Banaji, 2006; Blake \& Dennis, 1943; Williams, Best, Boswell, Mattson, \& Graves, 1975), whereas outside the USA, researchers have mainly focused on studying children's attitudes toward ethnic minorities relevant to their societies (Aboud \& Doyle, 1996; Griffiths \& Nesdale, 2006; Verkuyten, 2002). The main difficulties that these researchers encountered was to come up with a valid and reliable measurement method which was cheap and easy enough to implement in large samples, as well as accessible to children of different ages, and that children could easily understand (see Baron \& Banaji, 2006; Griffiths \& Nesdale, 2006).

In their attempts to measure children's attitudes, researchers applied an array of different techniques, most of them focusing on children's explicit attitudes or prejudice (Raabe \& Beelmann, 2011). Early researchers in the USA, for example, used lists of common stereotypes and "traits" and asked children to assign these traits to either whites or blacks (Blake \& Dennis, 1943). This method did not require children to understand complicated survey questions and used a simple language that children could understand. Other researchers, especially those interested in racial attitudes of very young children, chose to use pictures rather than simply worded questions, hoping to make their surveys even more comprehensible to children (e.g., Aboud, 1980; Goodman, 1952). While Goodman (1952) used pictures taken from magazines, Aboud (1980) used picture books with characters that represented different ethnicities. Both of them did not produce these pictures themselves for the purpose of measuring children's attitudes, and thus, the pictures may have included other elements which were not relevant for the studies, and to which children may possibly have reacted.

The Preschool Racial Attitude Measures-PRAM I and PRAM II (Williams et al., 1975) -were probably the first graphical stimuli specifically created in order to study children's attitudes. Children were shown 24 drawings, each depicting two individuals, one white and one black. Next, children were told a short story with either a positive or a negative adjective describing the main character. The children were finally asked to indicate which of the two persons the story referred to. This method gained popularity and was used in modified ways by various researchers later on (e.g., Aboud, 1988; BlackGutman \& Hickson, 1996).

Besides drawings, photographs have also been used as a common method to study children's attitudes toward racial minorities, led by the assumption that photographs are also more comprehensible to children and therefore easier to understand than verbal survey questions (Aboud, 1984; Griffiths \& Nesdale, 2006; Nesdale, Griffith, Durkin, \& Maass, 2005). To limit other clues (besides the ethnicity) possibly derived from photographs, some researchers chose to use headshots and dressed all photographed children in the same school uniform (Griffiths \& Nesdale, 2006; Nesdale et al., 2005).

Researchers have applied various rating methods to measure children's attitudes. Some researchers asked children to rate their feelings or indicate whether they would like to play with the portrayed child (Aboud, 1980; Maras \& Brown, 1996) using, for example, faces with different levels of a smiley for the rating (Aboud, 1980; see also Maras \& Brown, 1996). Others asked children to assign certain characteristics to the children portrayed in the pictures (Aboud, 1988; Black-Gutman \& Hickson, 1996; Griffiths \& Nesdale, 2006).

The variety of techniques demonstrates that no standardized procedures to measure children's attitudes toward minorities have been developed, rendering comparisons between studies and replications difficult. Furthermore, many of the methods required children to assign certain traits or to rank pre-defined individuals or groups in such a way that reflected their positive or negative attitudes toward each of them (Chigier \& Chigier, 1968; Richardson, Goodman, Hastorf, \& Dornbusch, 1961; Williams et al., 1975). This implied that children were not able to express positive or negative attitudes toward more than one individual or group (but see, e.g., Black-Gutman \& Hickson, 1996, or Doyle, Beaudet, \& Aboud, 1988, who developed a rating scale overcoming the latter problem). Finally, most of these methods were not applicable for larger-scale surveys because they required personal interviews with the children, thus rendering the data collection to be expensive 
and time-consuming and therefore resulting in small sample sizes.

Although useful, to the best of our knowledge to date, none of the above described techniques has been applied to a large-scale survey in order to measure children's attitudes toward ethnic minorities. Generally, there has been very limited large-scale research on children's attitudes toward minorities. In what follows, we present the set of picture-based questions used to build our instrument. Further, we validate the new instrument using unique, large-scale, panel, cross-country survey data, including children of different ages, several time points, and two countries, Poland and Switzerland.

\section{Method}

Picture-based measures of children's attitudes toward immigrants belonging to ethnic minorities

For our measurement instruments, we focused on the children's willingness for contact with other children with an immigration background. This aspect of attitudes toward immigrant children is closely related to the concept of social distance (Bogardus, 1925; Hindriks et al., 2014; Park, 1924). Because the measurement instruments asked children to rate their willingness of contact directly, they should be classified as explicit attitude measures.

We developed two pictures designed to describe a girl and a boy belonging to two groups of common immigrant minorities in Western European societies, Muslims and blacks. Each child or teenager participating in the survey was presented with both pictures (see Fig. 1). Each picture was introduced by a short description of the depicted children. To introduce the picture of the Muslim children, the following description was used:
"Mustafa and Salma are new in town. Mustafa and Salma's family are not from Switzerland/Poland." This description was followed by the picture and then by four questions: "Please imagine Mustafa or Salma attends the same school as you. To what extent do you agree with the following statements? I would be happy, (1) if one of them would live next to me (which we termed "neighbor"), (2) to be friends with one of them (which we termed "friend"), (3) to work on a school project with one of them (which we termed "school"), and (4) if one of them invited me over (which we termed "invite")." For the responses to each of these questions, a six-point scale ranging between "do not agree at all" and "fully agree" was used. The description and questions used for the picture of the black immigrant children were identical with the exception of the names; these were changed to Jamal and Laila. Detailed information on the items used and their concept affiliation can be found in Appendix 2.

\section{Data}

Data were collected between October 2015 and December 2016 in both Switzerland and Poland. The data collection was performed in classroom settings. This collection strategy was chosen because peers and classmates form an increasingly relevant part of children's social network. And the older children get, the more relevant friendship ties become (Berndt, 1986; Brown, Clasen, \& Eicher, 1986; Nickerson \& Nagle, 2005). The Polish data were collected in 36 schools and 127 classes in and around Warsaw. The Swiss data were collected in 12 schools and 68 classes in urban areas of the German-speaking regions. Data collection was administered online in Poland and
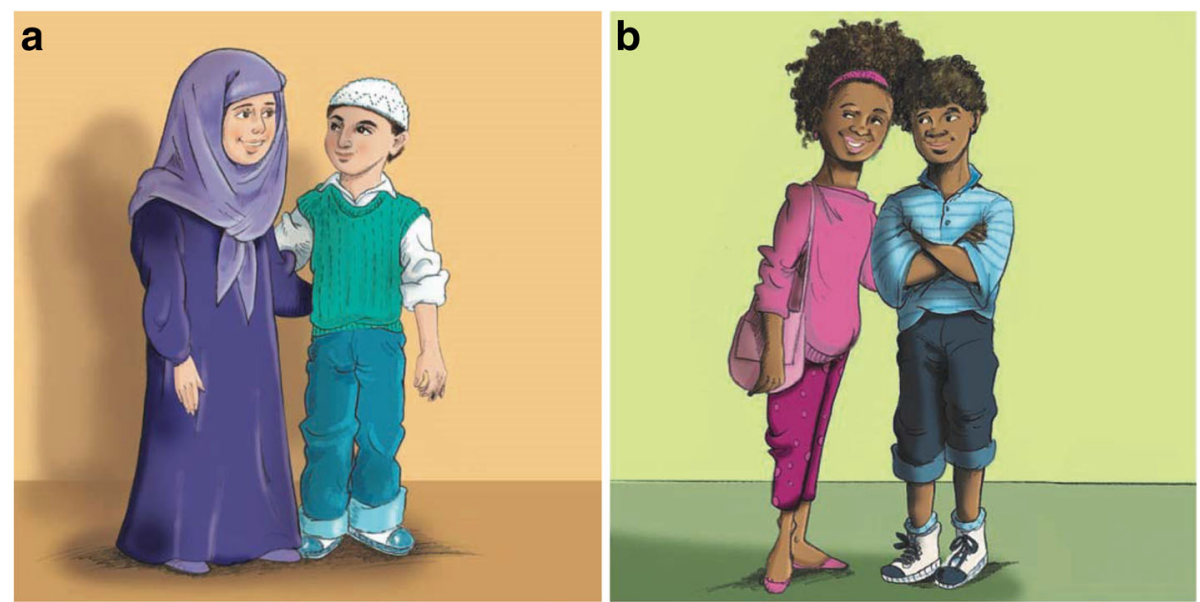

Fig. 1 Pictures used in the questionnaire. Left, Salma and Mustafa (Muslim). Right, Laila and Jamal (Black) 
using paper-and-pencil questionnaires in Switzerland. In both cases, trained research assistants were present during the data collection. Prior to each data collection, one of the researchers met with the teachers and headmasters, presented the project's goals and research questions in detail, and received the consent of the school authorities and individual schools' staff. The students and parents in Switzerland had the possibility to opt-out of the study, whereas in Poland, an opt-in written form signed by the parents was required. In Switzerland, only 10 out of 18 cantons contacted agreed that their schools participate in the survey. We did not encounter this problem in Poland, because a mandate received from the federal level allowed direct contact with the individual schools. Data were collected in a panel design with three waves, roughly half a year apart (wave 1 in October/ November 2015, wave 2 in February/March 2016, wave 3 in November/December 2016). Three cohorts participated in each country: the youngest cohort included pupils attending primary school. The middle cohort included pupils attending the 7 th grade (1st grade of the Polish gymnasium). Finally, the oldest cohort included pupils attending the 9th grade in Switzerland and the 10th grade in Poland (1st grade of the Polish lyceum). The sample included a total of 3819 children in Poland and 1513 children in Switzerland. In the first wave sample, $47.38 \%$ of the children were male and on average the children were 13.48 years old when first contacted. Appendix 1 presents the detailed sample sizes by country, cohort, and wave and provides the age and gender distribution of the pupils in each country sample. Thus, we had six groups in total in the sample: three age cohorts in Poland and an additional three age cohorts in Switzerland. For simplicity, we named the age cohorts young, middle, and old. All groups participated at each of the three measurement time points. However, some individuals dropped out in the course of the study. The rate of missing values (either for certain responses or due to dropout of children) was negligible. Dropout was not related systematically to any of the variables used in the analysis. The main source of missing values was the fact that some schools decided not to participate in later waves after they had participated in the first wave. However, other schools joined in later waves although they did not participate in the first wave. We used all available individuals in all waves and age cohorts in the two countries and addressed the problem of missing values using full information maximum likelihood (FIML: Schafer \& Graham, 2002) estimation. Further details on data collection are described by Kindschi et al. (2019).

\section{Approach}

We used confirmatory factor analyses (CFA; Brown, 2015) to measure children's attitudes toward immigrants belonging to ethnic minorities. First, we examined the latent variables to measure attitudes toward each immigrant minority separately. We used the four questions asked after introducing each picture as measurement items. First, we performed simultaneous single-group CFAs (SCFA), where the three waves were modeled simultaneously for each of the two attitude types, countries (2), and age cohorts (3) separately $(2 \times 2 \times 3=12$ models; model type 1 in Table 1). This was followed by a multi-group SCFA for each of the two attitude types. Each model had six groups: two countries $\times$ three age cohorts (model type 2 in Table 1). Figure 2 shows an illustration of a SCFA model of attitudes toward Muslim immigrants. The error correlations of the same question were allowed to covary over time (Finkel, 1995).

To test the reliability and validity of the measures, we proceeded in the following way. First, we inspected whether factor loadings were at least as high as 0.3 or 0.4 (Brown, 2015) to guarantee that each of the measures displayed an acceptable validity. Second, we examined whether the attitudes displayed measurement equivalence (Baumgartner \& Steenkamp, 1998) across age groups, measurement waves, and countries. Measurement equivalence may be a prerequisite for using the picture-based measurements for children's attitudes toward ethnic immigrant minorities in different contexts. We examined three levels of invariance. The lowest level, configural invariance, was assessed to guarantee that the same items may be used to measure children's attitudes across the groups. Metric invariance was assessed to guarantee that the factor loadings were similar across groups, thus, ensuring that pupils in different groups understand the questions similarly. Scalar invariance was assessed by inspecting whether the item intercepts were the same across groups, implying that response patterns of children were similar across groups. We performed this test using a multi-group confirmatory factor analysis (MGCFA; Brown, 2015; Davidov, Meuleman, Cieciuch, Schmidt, \& Billiet, 2014; Jöreskog, 1971).

Finally, we validated the measurements by examining their correlation with each other (model type 3 in Table 1; see also Fig. 3). In order to do so, we collapsed the data across age cohorts and used only the first wave. With that information, we performed multi-country analyses. A summary of the analyzed models can be found in Table 1 .

To determine the fit of the models, we relied on two global fit measures: the comparative fit index (CFI) and the root mean square error of approximation (RMSEA) (Arbuckle, 2016). A CFI value higher than 0.90 combined with an RMSEA value lower than 0.08 were interpreted as 
Table 1 Sequence of performed models

\begin{tabular}{ll}
\hline Model types & Number of models \\
\hline $\begin{array}{l}\text { 1. Single-group multi-wave SCFA (with } \\
3 \text { waves modeled simultaneously) }\end{array}$ & $\begin{array}{l}12 \text { models }(2 \text { countries } \times 2 \\
\text { attitude types } \times 3 \text { age cohorts) }\end{array}$ \\
$\begin{array}{ll}\text { 2. Multi-group multi-wave SCFAs (with } & 2 \text { models } \\
3 \text { waves modeled simultaneously) } & \begin{array}{l}1 \text { for each attitude types) } \\
\text { Each with } 6 \text { groups ( } 2 \\
\text { countries } \times 3 \text { age cohorts })\end{array} \\
\begin{array}{ll}\text { 3. Multi-country single-wave SCFA } \\
\text { (using only the first wave, age cohorts } \\
\text { collapsed together) }\end{array} & \text { groups ( } 2 \text { countries) }\end{array}$ \\
\hline
\end{tabular}

an acceptable fit (Hu \& Bentler, 1999; Marsh, Hau, \& Wen, 2004). To determine whether the different levels of measurement invariance were achieved, we evaluated the changes in these global fit measures between less and more restricted models. As the cutoff criteria, we used the ones proposed by Chen (2007). As long as the CFI drop from the less constrained to the more constrained model was smaller than 0.01 and the RMSEA increase was smaller than 0.015 (Chen, 2007), we accepted the higher level of equivalence (i.e., the more restricted model).

\section{Results}

\section{Attitudes toward Muslim children}

(1) Overall, the standardized factor loadings in the single-group models (model type 1 in Table 1 ) were high, ranging between 0.841 and 0.974 in the different age cohorts, waves, and countries (see Appendix 3 for standardized factor loadings). Cronbach's alpha was similarly high and ranged between 0.918 and 0.964 , depending on the wave and group considered. The correlation between the latent factors ranged between 0.387 and 0.701. In addition, the global fit measures in the different models were also very good (ranging between 0.970 and 0.999 for the CFI, and between 0.019 and 0.086 for the RMSEA) (see Appendix 3).

(2) The invariance test across age cohorts, waves, and countries (model type 2 in Table 1) constrained measurement parameters to be equal both across age cohorts, countries, and waves. It demonstrated that scalar invariance was given across all these dimensions (see Appendix 5 for the fit measures).

\section{Attitudes toward black children}

(1) Overall, the standardized factor loadings in the single-group models (model type 1 in Table 1) were high, ranging between 0.797 and 0.961 in the different age cohorts, waves, and countries (see Appendix 4 for standardized factor loadings). Cronbach's alpha was similarly high and ranged between 0.926 and 0.978 , depending on the wave and group considered. The correlation between the latent factors ranged between 0.281 and 0.709 . In addition, the global fit measures in the different models were also very good (ranging between 0.973 and 1.000 for the CFI, and

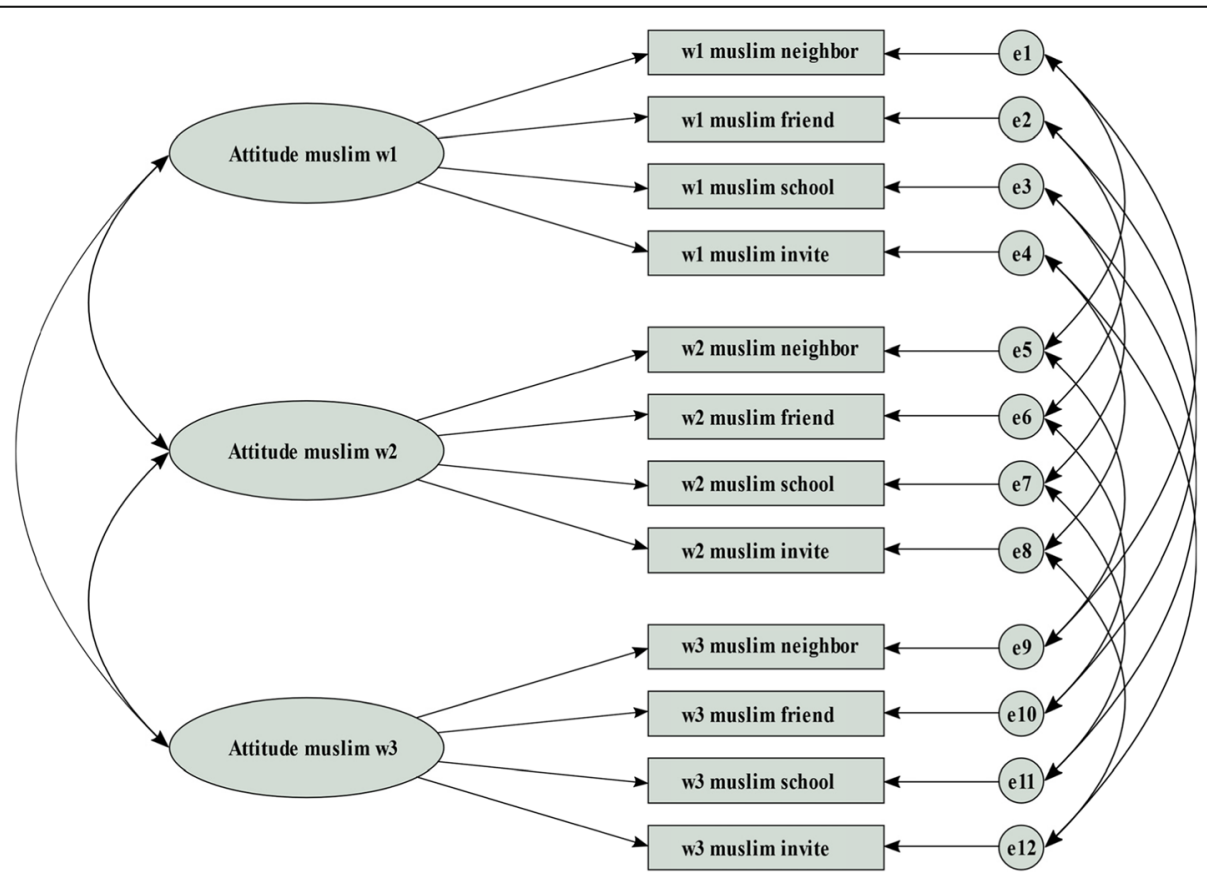

Fig. 2 SCFA for children's attitudes toward Muslim immigrants. Note: w1, w2, and w3 refer to the wave number 


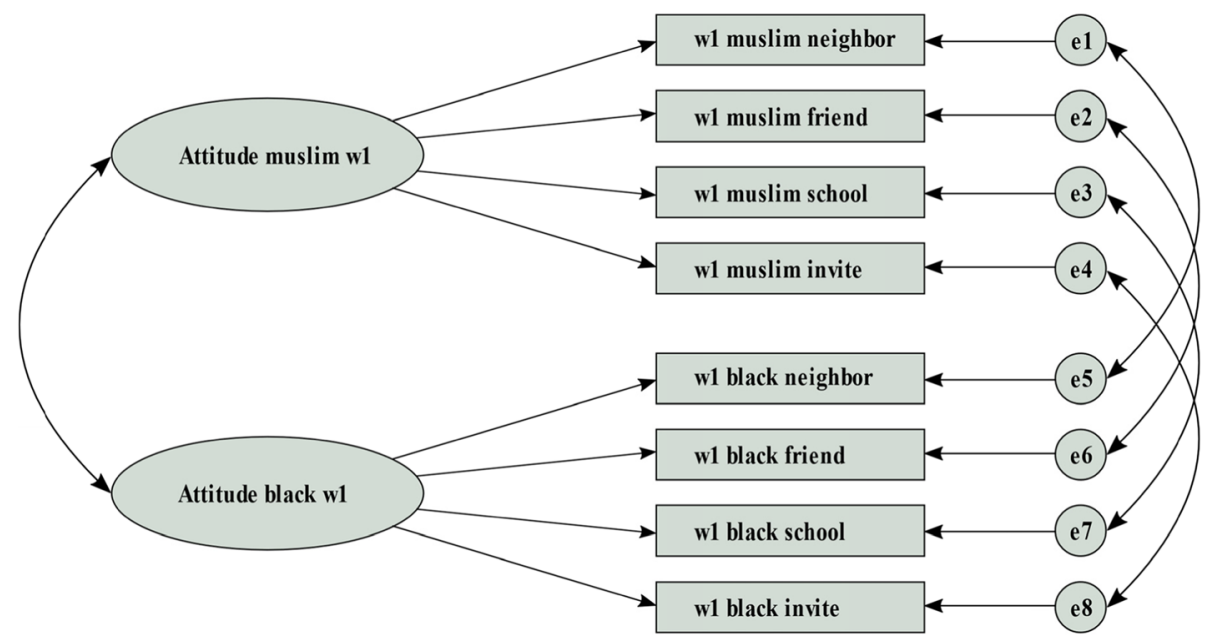

Fig. 3 Simultaneous factor analysis of attitudes toward Muslim and black immigrants

between 0.000 and 0.076 for the RMSEA) (see Appendix 4).

(2) The invariance test across age cohorts, countries, and waves (model type 2 in Table 1) constrained measurement parameters to be equal both across age cohorts, countries, and waves. It demonstrated that scalar invariance was given across all these dimensions (see Appendix 5 for the fit measures).

\section{A simultaneous factor analysis of attitudes toward Muslim and black children}

In the next step, we collapsed the age cohorts together and examined the measurement properties of attitudes toward both Muslim and black children simultaneously in each country in a multi-group comparison (model type 3 in Table 1, also see Fig. 3). As scalar invariance was evidenced across waves, only the first wave from each country was used.

The global fit measures were very good (configural invariance: $\mathrm{CFI}=0.995$; $\mathrm{RMSEA}=0.031$ ). The correlation between the two latent variables was positive and significant in Poland and Switzerland (0.621 and 0.803, respectively). Furthermore, the two factors displayed full scalar invariance across the two countries (scalar invariance: $\mathrm{CFI}=0.993$; $\mathrm{RMSEA}=0.031$; for more details, see Appendix 6).

\section{Discussion}

The high factor loadings, Cronbach's alpha reliabilities, and the longitudinal scalar invariance suggested that the introduced measurements for both attitudes toward Muslim and attitudes toward black immigrants were reliable and comparable. Furthermore, the invariance tests implied that the measures were understood similarly by children belonging to different age cohorts and at different time points as well as across countries. Their response patterns were similar enough to allow comparisons of the scores across all these groups. This again is true for both types of attitudes.

The simultaneous factor analysis of attitudes toward Muslim and black children displayed a very good fit to the data and showed a high correlation between the two attitude types. This was to be expected, since several authors have demonstrated that individuals displaying negative attitudes toward one minority group are likely to display negative attitudes also toward other minority groups (Zick et al., 2008). In addition, findings of scalar invariance across the two countries allow the comparison of unstandardized relations between the two concepts and their means across groups (Davidov, Meuleman, Schwartz, \& Schmidt, 2014).

The substantive coefficients suggested that the relation between attitudes toward Muslim and black children was significantly higher in Switzerland (covariance $=1.089$ ) than in Poland (covariance $=0.910$ ), and that on average pupils in Switzerland had significantly more positive attitudes toward both black and Muslim children $(M=4.744$ and $M=4.395$, respectively) than in Poland ( $M=4.463$ and $M=3.891$, respectively). Further group differences, obtained by analyzing additional models, can be found in Appendix 7. We were also able to show that the attitudes toward Muslim and black immigrants formed a secondorder factor. Detailed information on these models can be requested from the first author.

Overall, the results suggested that the introduced picture-based measurements of children's attitudes toward children belonging to an immigrant minority displayed high factor loadings, satisfactory model fit indices, and high levels of measurement equivalence across age cohorts, measurement waves, and countries. 
Therefore, the measurement and the design used here may constitute a potential tool to assess children's attitudes toward ethnic minorities, in particular black and Muslim children, in future studies conducted in Western countries.

The study is not without limitations. The picture-based attitude measures utilized pictures of two specific ethnic minority groups, blacks and Muslims. However, in different societies, researchers may be interested in the measurement of children's attitudes toward other ethnic minorities, which would require developing other pictures that are more appropriate to tap into attitudes toward immigrants of other ethnic minority groups. Developing such pictures may be more time-consuming than designing verbal survey questions. In addition, our study was administered in two countries only. Therefore, although likely, this makes it still difficult to conclude whether the measures would operate well also in other countries.

Furthermore, our data did not include information on the socioeconomic status or the immigration background of the children who responded to our questionnaire or of other potentially relevant criterion variables such as other prejudice measures. Thus, we could not assess how the picture-based measures operated across children belonging to different groups thereof or further externally validate our measures.

Another issue concerning the validity of the instrument is the possibility that the children did not focus on the intended clues (ethnicity), but on other features of the picture (facial expressions, background, etc.). This is a general problem when using picture-based measures. In order to decrease this risk in our study, we designed the instrument in a way that should minimize potential distractions: The complementary texts preceding the pictures already introduce the topic of immigrants, shifting the children's attention to it, and the pictures themselves include very few other clues. ${ }^{1}$

\footnotetext{
${ }^{1}$ Further, we collected additional data among adults and asked respondents to name the most prominent feature of each figure. Most adults named the ethnicity, race, or religion of the depicted children, providing support for the face validity of the instrument. Furthermore, we examined the criterion validity of the picture-based measures in the adult sample by examining their correlations with established instruments such as questions measuring contact quality with or threat due to immigrants and the willingness to allow immigrants into the country. Our instruments displayed moderate to strong correlations with these measures, supporting their criterion-related validity. Finally, scalar invariance of the picture-based measures was established across the adults and the Swiss and Polish children samples. Additional information on these analyses may be obtained from the first author upon request.
}

Lastly, the questionnaire did not include any questions on the children's attitudes toward children who do not have a migration background and do not belong to a minority group. Therefore, we were unable to compare the attitudes toward children belonging to either of the two immigrant groups with attitudes toward non-immigrant children. This is also the case in many major surveys. Like ours, these surveys focus on the measurement of attitudes toward minority groups. The computed attitude score is then rather arbitrary. The score becomes meaningful when compared to other groups. From this point of view, our measures should be interpreted in light of their relation to the same measures in other groups. In our study these groups, were countries and time points (see Appendix 7 for a comparison also across age and gender groups), but other groups of theoretical and empirical interest could be considered as well. Researchers who are interested in comparing attitudes toward minority and majority group members among children could develop in future studies similar visual measures of attitudes toward majority group members (e.g., non-immigrant Swiss- or Polish-born children). When doing so, it would be important to pay particular attention to varying only the immigration status of the children in the pictures while keeping everything else equal. While this may be more challenging than developing verbal questions measuring attitudes toward different groups, it would bear the chance of enhancing the measurement of attitudes toward different groups also among younger children.

However, in spite of these limitations, the collection of attitudes among children using the proposed pictures bears the potential of allowing researchers to more closely examine developmental processes of these attitudes already at early age.

\section{Conclusion}

In sum, the findings suggest that our picture-based measures may introduce a useful tool to assess children's attitudes toward Muslim and black immigrant minorities in Western societies. Once the agreement of schools or parents is given, this tool may be rather time and cost-efficient, as it enables distributing selfadministered questionnaires to children rather than requiring individual interviews with each participating child. It is rather easily applicable to children, childfriendly, likely to result in equivalent measures across children of different age or cultural background and reduces the need of complicated translation procedures. 


\section{Appendix 1}

Table 2 Study design: sample sizes, age, and gender distributions per country, age cohorts, and waves

\begin{tabular}{|c|c|c|c|c|c|c|c|c|c|c|c|c|c|c|c|c|c|c|}
\hline Country & \multicolumn{9}{|c|}{ Switzerland $(\mathrm{CH})$} & \multicolumn{9}{|c|}{ Poland (PL) } \\
\hline $\begin{array}{l}N \\
\text { Countries }\end{array}$ & \multicolumn{9}{|l|}{1,513} & \multicolumn{9}{|l|}{3,819} \\
\hline Age group & \multicolumn{3}{|c|}{$\mathrm{CH}$-young } & \multicolumn{3}{|c|}{$\mathrm{CH}$-middle } & \multicolumn{3}{|l|}{$\mathrm{CH}$-old } & \multicolumn{3}{|c|}{ PL-young } & \multicolumn{3}{|c|}{ PL-middle } & \multicolumn{3}{|l|}{ PL-old } \\
\hline $\begin{array}{l}N \\
\text { Age groups }\end{array}$ & \multicolumn{3}{|l|}{253} & \multicolumn{3}{|l|}{828} & \multicolumn{3}{|l|}{432} & \multicolumn{3}{|l|}{433} & \multicolumn{3}{|l|}{1,554} & \multicolumn{3}{|l|}{1,832} \\
\hline Wave & 1 & 2 & 3 & 1 & 2 & 3 & 1 & 2 & 3 & 1 & 2 & 3 & 1 & 2 & 3 & 1 & 2 & 3 \\
\hline $\begin{array}{l}\text { Age range, } \\
\text { mean, } \\
\text { (SD) }\end{array}$ & $\begin{array}{l}8-12 \\
9.65 \\
(0.81)\end{array}$ & $\begin{array}{l}8-12 \\
9.69 \\
(0.84)\end{array}$ & $\begin{array}{l}9-12 \\
10.57 \\
(0.74)\end{array}$ & $\begin{array}{l}11-14 \\
12.56 \\
(0.60)\end{array}$ & $\begin{array}{l}11-14 \\
12.55 \\
(0.60)\end{array}$ & $\begin{array}{l}12-15 \\
13.43 \\
(0.63)\end{array}$ & $\begin{array}{l}12-17 \\
14.42 \\
(0.69)\end{array}$ & $\begin{array}{l}12-17 \\
14.40 \\
(0.68)\end{array}$ & $\begin{array}{l}14-18 \\
15.40 \\
(0.72)\end{array}$ & $\begin{array}{l}8-11 \\
9.74 \\
(0.53)\end{array}$ & $\begin{array}{l}9-12 \\
10.21 \\
(0.63)\end{array}$ & $\begin{array}{l}9-13 \\
10.86 \\
(0.53)\end{array}$ & $\begin{array}{l}12-16 \\
12.91 \\
(0.40)\end{array}$ & $\begin{array}{l}12-16 \\
13.43 \\
(0.57)\end{array}$ & $\begin{array}{l}12-17 \\
13.96 \\
(0.41)\end{array}$ & $\begin{array}{l}15-19 \\
16.00 \\
(0.41)\end{array}$ & $\begin{array}{l}14-19 \\
16.42 \\
(0.56)\end{array}$ & $\begin{array}{l}15-19 \\
17.01 \\
(0.37)\end{array}$ \\
\hline $\begin{array}{l}\text { Gender } \\
\text { (\% male) }\end{array}$ & 54.35 & 53.21 & 51.30 & 48.65 & 47.38 & 46.48 & 44.01 & 43.09 & 41.51 & 51.97 & 52.19 & 51.06 & 48.49 & 46.38 & 47.90 & 40.90 & 40.62 & 37.58 \\
\hline $\begin{array}{l}N \\
\text { Waves }\end{array}$ & 184 & 156 & 115 & 742 & 686 & 497 & 384 & 362 & 212 & 279 & 274 & 235 & 827 & 871 & 739 & 1,005 & 933 & 737 \\
\hline
\end{tabular}

SD Standard deviation

\section{Appendix 2}

Table 3 Distribution and concept affiliation of the items used in the analyses

\begin{tabular}{|c|c|c|c|c|c|}
\hline Concept & Items & Mean (SD) & $N$ & Skewness & Kurtosis \\
\hline \multirow[t]{4}{*}{ Attitudes toward Muslim immigrants } & muslim neighbor & $4.05(1.33)$ & 4245 & -0.61 & 2.76 \\
\hline & muslim friend & $4.08(1.34)$ & 4243 & -0.59 & 2.72 \\
\hline & muslim school & $4.08(1.34)$ & 4244 & -0.63 & 2.77 \\
\hline & muslim invite & $3.93(1.39)$ & 4244 & -0.46 & 2.45 \\
\hline \multirow[t]{4}{*}{ Attitudes toward black immigrants } & black neighbor & $4.57(1.14)$ & 4247 & -0.96 & 3.91 \\
\hline & black friend & $4.62(1.14)$ & 4246 & -1.01 & 4.00 \\
\hline & black school & $4.54(1.16)$ & 4245 & -0.96 & 3.82 \\
\hline & black invite & $4.47(1.21)$ & 4246 & -0.86 & 3.42 \\
\hline
\end{tabular}

Means and standard deviations (SD) calculated across all groups and all time points 


\section{Appendix 3}

Table 4 SCFA models for attitudes toward Muslim immigrants modeled separately across age cohorts and countries (configural model) (with standardized factor loadings)

\begin{tabular}{|c|c|c|c|c|c|c|}
\hline & CH-young & PL-young & CH-middle & PL-middle & CH-old & PL-old \\
\hline \multicolumn{7}{|l|}{ Factor loadings } \\
\hline w1 muslim neighbor & 0.869 & 0.865 & 0.875 & 0.879 & 0.882 & 0.917 \\
\hline w1 muslim friend & 0.955 & 0.938 & 0.922 & 0.934 & 0.937 & 0.969 \\
\hline w1 muslim school & 0.913 & 0.844 & 0.887 & 0.922 & 0.881 & 0.950 \\
\hline w1 muslim invite & 0.886 & 0.841 & 0.870 & 0.892 & 0.873 & 0.944 \\
\hline w2 muslim neighbor & 0.913 & 0.920 & 0.898 & 0.907 & 0.895 & 0.923 \\
\hline w2 muslim friend & 0.943 & 0.932 & 0.938 & 0.950 & 0.947 & 0.968 \\
\hline w2 muslim school & 0.935 & 0.917 & 0.890 & 0.936 & 0.874 & 0.951 \\
\hline w2 muslim invite & 0.917 & 0.843 & 0.875 & 0.912 & 0.868 & 0.953 \\
\hline w3 muslim neighbor & 0.929 & 0.923 & 0.922 & 0.909 & 0.890 & 0.939 \\
\hline w3 muslim friend & 0.966 & 0.953 & 0.948 & 0.954 & 0.941 & 0.974 \\
\hline w3 muslim school & 0.926 & 0.951 & 0.925 & 0.960 & 0.945 & 0.967 \\
\hline w3 muslim invite & 0.922 & 0.873 & 0.903 & 0.924 & 0.923 & 0.950 \\
\hline \multicolumn{7}{|l|}{ Cronbach's alpha } \\
\hline Items w1 & 0.947 & 0.926 & 0.937 & 0.948 & 0.940 & 0.971 \\
\hline Items w2 & 0.960 & 0.946 & 0.944 & 0.960 & 0.942 & 0.973 \\
\hline Items w3 & 0.965 & 0.959 & 0.959 & 0.966 & 0.959 & 0.978 \\
\hline \multicolumn{7}{|c|}{ Correlations among latent variables } \\
\hline w1 with w2 & 0.654 & 0.436 & 0.563 & 0.525 & 0.624 & 0.642 \\
\hline w1 with w3 & 0.674 & 0.431 & 0.387 & 0.422 & 0.548 & 0.537 \\
\hline w2 with w3 & 0.701 & 0.432 & 0.484 & 0.505 & 0.575 & 0.548 \\
\hline \multicolumn{7}{|l|}{ Global fit measures } \\
\hline $\mathrm{CFI}$ & 0.970 & 0.993 & 0.999 & 0.995 & 0.990 & 0.998 \\
\hline RMSEA & 0.086 & 0.036 & 0.019 & 0.032 & 0.048 & 0.023 \\
\hline
\end{tabular}

CFI comparative fit index, RMSEA root mean square error of approximation 


\section{Appendix 4}

Table 5 SCFA models for attitudes toward black immigrants modeled separately across age cohorts and countries (configural model) (with standardized factor loadings)

\begin{tabular}{|c|c|c|c|c|c|c|}
\hline & CH-young & PL-young & $\mathrm{CH}$-middle & PL-middle & CH-old & PL-old \\
\hline \multicolumn{7}{|l|}{ Factor loadings } \\
\hline w1 black neighbor & 0.870 & 0.855 & 0.863 & 0.863 & 0.870 & 0.866 \\
\hline w1 black friend & 0.934 & 0.912 & 0.914 & 0.934 & 0.916 & 0.952 \\
\hline w1 black school & 0.899 & 0.898 & 0.867 & 0.904 & 0.809 & 0.938 \\
\hline w1 black invite & 0.880 & 0.797 & 0.857 & 0.853 & 0.848 & 0.927 \\
\hline w2 black neighbor & 0.876 & 0.920 & 0.889 & 0.893 & 0.882 & 0.897 \\
\hline w2 black friend & 0.924 & 0.939 & 0.913 & 0.921 & 0.915 & 0.941 \\
\hline w2 black school & 0.927 & 0.912 & 0.856 & 0.909 & 0.868 & 0.942 \\
\hline w2 black invite & 0.876 & 0.832 & 0.864 & 0.857 & 0.869 & 0.923 \\
\hline w3 black neighbor & 0.906 & 0.869 & 0.913 & 0.914 & 0.887 & 0.887 \\
\hline w3 black friend & 0.936 & 0.941 & 0.954 & 0.946 & 0.937 & 0.960 \\
\hline w3 black school & 0.954 & 0.925 & 0.918 & 0.936 & 0.876 & 0.961 \\
\hline w3 black invite & 0.893 & 0.834 & 0.862 & 0.906 & 0.945 & 0.925 \\
\hline \multicolumn{7}{|l|}{ Cronbach's alpha } \\
\hline Items w1 & 0.942 & 0.922 & 0.928 & 0.937 & 0.918 & 0.957 \\
\hline Items w2 & 0.945 & 0.944 & 0.931 & 0.941 & 0.933 & 0.960 \\
\hline Items w3 & 0.958 & 0.939 & 0.951 & 0.960 & 0.950 & 0.964 \\
\hline \multicolumn{7}{|c|}{ Correlations among latent variables } \\
\hline w1 with w2 & 0.536 & 0.452 & 0.568 & 0.399 & 0.602 & 0.585 \\
\hline w1 with w3 & 0.584 & 0.281 & 0.397 & 0.398 & 0.505 & 0.442 \\
\hline w2 with w3 & 0.709 & 0.415 & 0.470 & 0.376 & 0.541 & 0.403 \\
\hline \multicolumn{7}{|l|}{ Global fit measures } \\
\hline $\mathrm{CFI}$ & 0.973 & 1 & 0.992 & 0.993 & 0.993 & 0.994 \\
\hline RMSEA & 0.076 & 0 & 0.045 & 0.034 & 0.038 & 0.034 \\
\hline
\end{tabular}

CFI comparative fit index, RMSEA root mean square error of approximation

\section{Appendix 5}

Table 6 Global fit measures from the multigroup SCFA testing for measurement invariance across age cohorts, waves, and countries

\begin{tabular}{lll}
\hline & CFI & RMSEA \\
\hline Attitudes toward Black immigrants & 0.970 & 0.028 \\
Configural invariance & 0.969 & 0.027 \\
Metric invariance & 0.969 & 0.026 \\
Metric invariance with stable effects over time & 0.963 & 0.027 \\
Scalar invariance & 0.961 & 0.027 \\
Scalar invariance with stable effects over time & & \\
Attitudes toward Muslim immigrants & 0.981 & 0.024 \\
Configural invariance & 0.981 & 0.022 \\
Metric invariance & 0.981 & 0.022 \\
Metric invariance with stable effects over time & 0.978 & 0.023 \\
Scalar invariance & 0.977 & 0.023 \\
Scalar invariance with stable effects over time &
\end{tabular}

CFI comparative fit index, RMSEA root mean square error of approximation

\section{Appendix 6}

Table $\mathbf{7}$ Global fit measures from the SCFA of attitudes toward Muslim and black immigrants

\begin{tabular}{lll}
\hline & CFI & RMSEA \\
\hline Configural invariance & 0.995 & 0.031 \\
Metric invariance & 0.995 & 0.029 \\
Scalar invariance & 0.993 & 0.031 \\
\hline CFI comparative fit index, RMSEA root mean square error of approximation
\end{tabular}




\section{Appendix 7}

Table $\mathbf{8}$ Group differences in the attitude means across country, age, and gender

\begin{tabular}{|c|c|c|c|c|c|}
\hline & \multicolumn{2}{|l|}{$\begin{array}{l}\text { Mean (SD) } \\
\text { Attitude toward }\end{array}$} & \multirow[t]{2}{*}{ Correlation } & \multirow[t]{2}{*}{ CFI } & \multirow[t]{2}{*}{ RMSEA } \\
\hline & Black immigrants & Muslim immigrants & & & \\
\hline \multicolumn{6}{|l|}{ Country } \\
\hline Switzerland & 4.744 & 4.395 & 0.803 & 0.993 & 0.031 \\
\hline Poland & 4.463 & 3.891 & 0.621 & & \\
\hline \multicolumn{6}{|l|}{ Age group } \\
\hline Young & 4.218 & 4.043 & 0.711 & 0.995 & 0.022 \\
\hline Middle & 4.651 & 4.215 & 0.736 & & \\
\hline Old & 4.594 & 3.942 & 0.657 & & \\
\hline \multicolumn{6}{|l|}{ Gender } \\
\hline Male & 4.313 & 3.755 & 0.667 & 0.995 & 0.026 \\
\hline Female & 4.789 & 4.366 & 0.692 & & \\
\hline
\end{tabular}

Results reported from multi-group single-wave SCFA models with scalar invariance (similar to Model type 3 in Table 1). Correlation correlation between the two attitudes, CFI comparative fit index under scalar invariance, RMSEA root mean square error of approximation under scalar invariance

\section{Supplementary information}

Supplementary information accompanies this paper at https://doi.org/10. 1186/s42409-020-00017-0.

Additional file 1. The file contains all cases and variables used for the above analyses.

Additional file 2. This data set contains the additional information gathered on adults.

\section{Acknowledgements}

The authors would like to thank Lisa Trierweiler for the English proof of the manuscript.

\section{Authors' contributions}

The data was collected and organized by E.D., J.C., R.A., and M.K. The analyses were performed by C.C.B. and the article was written by C.C.B. All authors were involved in commenting on and revising the first draft of the article. The author(s) read and approved the final manuscript.

\section{Funding}

The work of the authors was supported by the University of Zurich Research Priority Program Social Networks. The Polish data was collected within the 2014/14/M/HS6/00919 Grant from the National Science Center, Poland. Neither of the organizations exerted influence on the choice of study design, the analysis, or the interpretation of the data. Open Access funding enabled and organized by Projekt DEAL.

\section{Availability of data and materials}

The full dataset is currently not publicly available. The part of the dataset supporting the conclusions of this article is included within the article and its additional files (see Additional file 1).

\section{Ethics approval and consent to participate}

Prior to each data collection, one of the researchers met with the teachers and headmasters, presented the project's goals and research questions in detail, and received the consent of the school authorities and individual schools' staff. The students and parents in Switzerland had the possibility to opt-out of the study, whereas in Poland, an opt-in written form signed by the parents was required. In Switzerland, only 10 out of 18 cantons contacted agreed that their schools participate in the survey. We did not encounter this problem in Poland, because a mandate received from the federal level allowed direct contact with the individual schools.
Consent for publication

Not applicable.

\section{Competing interests}

Not applicable.

\section{Author details}

${ }^{1}$ Cologne Graduate School in Management, Economics and Social Sciences and Institute of Sociology and Social Psychology, University of Cologne, Albertus-Magnus-Platz, 50923 Cologne, Germany. ${ }^{2}$ Institute of Sociology and Social Psychology, University of Cologne, Cologne, Germany. ${ }^{3}$ URPP Social Networks, University of Zurich, Zurich, Switzerland. ${ }^{4}$ Department of Sociology, University of Zurich, Zurich, Switzerland. ${ }^{5}$ Institute of Psychology, Cardinal Stefan Wyszyński University in Warsaw, Warsaw, Poland. ${ }^{6}$ Department of Business Administration, URPP Social Networks, University of Zurich, Zurich, Switzerland. ${ }^{7}$ Jacobs Center for Productive Youth Development, University of Zurich, Zurich, Switzerland.

Received: 24 January 2020 Accepted: 28 September 2020

Published online: 09 November 2020

\section{References}

Aboud, F. E. (1980). A test of ethnocentrism with young children. Canadian Journal of Behavioural Science/Revue Canadienne Des Sciences Du Comportement, 12(3), 195-209. https://doi.org/10.1037/h0081064.

Aboud, F. E. (1984). Social and cognitive bases of ethnic identity constancy. The Journal of Genetic Psychology, 145(2), 217-229. https://doi.org/10.1080/ 00221325.1984 .10532269 .

Aboud, F. E. (1988). Children and prejudice. Cambridge: B. Blackwell.

Aboud, F. E. (2008). A social-cognitive developmental theory of prejudice. In S. M. Quintana, \& C. McKown (Eds.), Handbook of race, racism, and the developing child, (pp. 55-71). John Wiley \& Sons, Inc. https://doi.org/10.1002/ 9781118269930.ch4.

Aboud, F. E., \& Doyle, A.-B. (1996). Does talk of race foster prejudice or tolerance in children? Canadian Journal of Behavioural Science/Revue Canadienne Des Sciences Du Comportement, 28(3), 161-170. https://doi.org/10.1037/0008400X.28.3.161.

Akkerman, T., de Lange, S. L., \& Rooduijn, M. (Eds.) (2016). Radical right-wing populist parties in Western Europe: Into the mainstream? New York: Routledge.

Alwin, D. F., \& Krosnick, J. A. (1991). Aging, cohorts, and the stability of sociopolitical orientations over the life span. American Journal of Sociology, 97(1), 169-195. https://doi.org/10.1086/229744.

Arbuckle, J. L. (2016). Amos 24.0 user's guide. Chicago: IBM SPSS.

Aydin, N., Krueger, J. I., Frey, D., Kastenmüller, A., \& Fischer, P. (2014). Social exclusion and xenophobia: Intolerant attitudes toward ethnic and religious 
minorities. Group Processes \& Intergroup Relations, 17(3), 371-387. https://doi. org/10.1177/1368430213510569.

Baron, A. S., \& Banaji, M. R. (2006). The development of implicit attitudes: Evidence of race evaluations from ages 6 and 10 and adulthood. Psychological Science, 17(1), 53-58. https://doi.org/10.1111/j.1467-9280.2005. 01664.x.

Baumgartner, H., \& Steenkamp, J.-B. E. M. (1998). Assessing measurement invariance in cross-national consumer research. Journal of Consumer Research, 25(1), 78-90. https://doi.org/10.1086/209528.

Berndt, T. J. (1986). Children's comments about their friendships. In M. Perlmutter (Ed.), The Minnesota Symposia on Child Psychology (18), (pp. 189-212). Hillsdale: Lawrence Erlbaum Associates.

Berry, J. W., \& Kalin, R. (1995). Multicultural and ethnic attitudes in Canada: An overview of the 1991 National Survey. Canadian Journal of Behavioural Science/Revue Canadienne Des Sciences Du Comportement, 27(3), 301-320. https://doi.org/10.1037/0008-400X.27.3.301

Berthoff, R. T. (1951). Southern attitudes toward immigration, 1865-1914. The Journal of Southern History, 17(3), 328-360. https://doi.org/10.2307/2198190.

Black-Gutman, D., \& Hickson, F. (1996). The relationship between racial attitudes and social-cognitive development in children: An Australian study. Developmental Psychology, 32(3), 448-456. https://doi.org/10.1037/0012-1649. 32.3.448.

Blake, R., \& Dennis, W. (1943). The development of stereotypes concerning the Negro. The Journal of Abnormal and Social Psychology, 38(4), 525-531. https:// doi.org/10.1037/h0057081.

Bogardus, E. S. (1925). Measuring social distance. Journal of Applied Sociology, 9, 299-308.

Brown, B. B., Clasen, D. R., \& Eicher, S. A. (1986). Perceptions of peer pressure, peer conformity dispositions, and self-reported behavior among adolescents. Developmental Psychology, 22(4), 521-530. https://doi.org/10.1037/0012-1649. 22.4.521.

Brown, T. A. (2015). Confirmatory factor analysis for applied research, (2nd ed., ). New York: The Guilford Press.

Chen, F. F. (2007). Sensitivity of goodness of fit indexes to lack of measurement invariance. Structural Equation Modeling, 14(3), 464-504. https://doi.org/10 1080/10705510701301834

Chigier, E., \& Chigier, M. (1968). Attitudes to disability of children in the multicultural society of Israel. Journal of Health and Social Behavior, 9(4), 310-317. https://doi.org/10.2307/2948539.

Cieciuch, J., Döring, A. K., \& Harasimczuk, J. (2013). Measuring Schwartz's values in childhood: Multidimensional scaling across instruments and cultures European Journal of Developmental Psychology, 10(5), 625-633. https://doi. org/10.1080/17405629.2012.707779.

Davidov, E., Cieciuch, J., Meuleman, B., Schmidt, P., Algesheimer, R., \& Hausherr, M. (2015). The comparability of measurements of attitudes toward immigration in the European Social Survey. Public Opinion Quarterly, 79(1), 244-266. https://doi.org/10.1093/poq/nfv008.

Davidov, E., Cieciuch, J., \& Schmidt, P. (2018). The cross-country measurement comparability in the immigration module of the European Social Survey 2014-15. Survey Research Methods, 12(1), 15-27. https://doi.org/10.18148/srm/ 2018.v12i1.7212.

Davidov, E., Meuleman, B., Cieciuch, J., Schmidt, P., \& Billiet, J. (2014). Measurement equivalence in cross-national research. Annual Review of Sociology, 40(1), 55-75. https://doi.org/10.1146/annurev-soc-071913-043137.

Davidov, E., Meuleman, B., Schwartz, S. H., \& Schmidt, P. (2014). Individual values, cultural embeddedness, and anti-immigration sentiments: Explaining differences in the effect of values on attitudes toward immigration across Europe. KZfSS Kölner Zeitschrift Für Soziologie Und Sozialpsychologie, 66(1), 263-285. https://doi.org/10.1007/s11577-014-0274-5.

De Graaf, P. M., Kalmijn, M., Kraaykamp, G., \& Monden, C. (2010). Design and content of the Netherlands Longitudinal Lifecourse Study (NELLS) [Data set]. Nijmegen: Tilburg University and Radboud University.

Decker, O., \& Brähler, E. (Eds.) (2018). Flucht ins Autoritäre. Rechtsextreme Dynamiken in der Mitte der Gesellschaft. Die Leipziger Autoritarismus-Studie 2018 [Escape to the Authoritarian. Right-wing extremist dynamics in the middle of society. The 20018 Leipzig authoritarianism study]. Gießen: Psychosozial-Verlag.

Donald, D. R. (1979). Effects of illustrations on early oral reading accuracy, strategies and comprehension. British Journal of Educational Psychology, 49(3), 282-289. https://doi.org/10.1111/j.2044-8279.1979.tb02427.x.

Döring, A. K., Blauensteiner, A., Aryus, K., Drögekamp, L., \& Bilsky, W. (2010). Assessing values at an early age: The Picture-Based Value Survey for Children
(PBVS-C). Journal of Personality Assessment, 92(5), 439-448. https://doi.org/10. 1080/00223891.2010.497423.

Doyle, A.-B., Beaudet, J., \& Aboud, F. (1988). Developmental patterns in the flexibility of children's ethnic attitudes. Journal of Cross-Cultural Psychology, 19(1), 3-18. https://doi.org/10.1177/0022002188019001001.

Eagly, A. H., \& Chaiken, S. (1998). Attitude structure and function. In D. T. Gilbert, S. T. Fiske, \& G. Lindzey (Eds.), The handbook of social psychology, (4th ed., pp. 269-322). Oxford Univeristy Press.

Eid, M., \& Diener, E. (2006). Handbook of multimethod measurement in psychology. Washington, DC: American Psychological Association. https//doi.org/10.1037/11383-000,

Esses, V. M., Jackson, L. M., \& Armstrong, T. L. (1998). Intergroup competition and attitudes toward immigrants and immigration: An instrumental model of group conflict. Journal of Social Issues, 54(4), 699-724. https://doi.org/10.1111/ j.1540-4560.1998.tb01244.x.

European Social Survey. (2018). ESS 1-8, European Social Survey cumulative file, Study description. doi.https://doi.org/10.21338/NSD-ESS-CUMULATIVE

Fang, Z. (1996). Illustrations, text, and the child reader: What are pictures in children's storybooks for? Reading Horizons, 37(2), 130-142 Retrieved from https://scholarworks.wmich.edu/reading_horizons/vol37/iss2/3.

Finkel, S. E. (1995). Causal analysis with panel data. Thousand Oaks: Sage Publications.

Glenberg, A. M., \& Langston, W. E. (1992). Comprehension of illustrated text: Pictures help to build mental models. Journal of Memory and Lanquage, 31(2), 129-151. https://doi.org/10.1016/0749-596X(92)90008-L.

Gómez-Pérez, E., \& Ostrosky-Solís, F. (2006). Attention and memory evaluation across the life span: Heterogeneous effects of age and education. Journal of Clinical and Experimental Neuropsychology, 28(4), 477-494. https://doi.org/10. 1080/13803390590949296.

Goodman, M. E. (1952). Race awareness in young children. Oxford, England: Addison-Wesley Press.

Griffiths, J. A., \& Nesdale, D. (2006). In-group and out-group attitudes of ethnic majority and minority children. International Journal of Intercultural Relations, 30(6), 735-749. https://doi.org/10.1016/j.ijintrel.2006.05.001.

Harter, S., \& Pike, R. (1984). The Pictorial Scale of Perceived Competence and Social Acceptance for Young Children. Child Development, 55(6), 1969-1982. https://doi.org/10.2307/1129772.

Heath, A., Richards, L., Davidov, E., Ford, R., Green, E., Ramos, A., \& Schmidt, P. (2016). Attitudes towards immigration and their antecedents: Topline results from round 7 of the European Social Survey. ESS7 Rotating Modules, European Social Survey. London: Centre for Comparative Social Surveys, City University.

Hindriks, P., Verkuyten, M., \& Coenders, M. (2014). Interminority attitudes: The roles of ethnic and national identification, contact, and multiculturalism. Social Psychology Quarterly, 77(1), 54-74. https://doi.org/10.1177/ 0190272513511469.

Hu, L., \& Bentler, P. M. (1999). Cutoff criteria for fit indexes in covariance structure analysis: Conventional criteria versus new alternatives. Structural Equation Modeling, 6(1), 1-55. https://doi.org/10.1080/10705519909540118.

ISSP Research Group (2015). International Social Survey Programme: National Identity III - ISSP 2013 [Data set]. https://doi.org/10.4232/1.12312.

Jöreskog, K. G. (1971). Simultaneous factor analysis in several populations. Psychometrika, 36(4), 409-426. https://doi.org/10.1007/BF02291366.

Kindschi, M., Cieciuch, J., Davidov, E., Ehlert, A., Rauhut, H., Tessone, C. J., \& Algesheimer, R. (2019). Values in adolescent friendship networks. Networking Science, 7(4), 498-522. https://doi.org/10.1017/nws.2019.16.

Krech, D., Crutchfield, R. S., \& Ballachey, E. L. (1962). Individual in society: A textbook of social psychology. McGraw-Hill.

La Greca, A. M. (1990). Through the eyes of the child: Obtaining self-reports from children and adolescents. Needham Heights: Allyn \& Bacon.

Maras, P., \& Brown, R. (1996). Effects of contact on children's attitudes toward disability: A longitudinal study. Journal of Applied Social Psychology, 26(23), 2113-2134. https://doi.org/10.1111/j.1559-1816.1996.tb01790.x.

Marsh, H. W., Hau, K.T., \& Wen, Z. (2004). In search of golden rules: Comment on hypothesis-testing approaches to setting cutoff values for fit indexes and dangers in overgeneralizing Hu and Bentler's (1999) findings. Structural Equation Modeling, 11(3), 320-341. https://doi.org/10.1207/s15328007sem1103_2.

Nesdale, D., Griffith, J., Durkin, K., \& Maass, A. (2005). Empathy, group norms and children's ethnic attitudes. Journal of Applied Developmental Psychology, 26(6), 623-637. https://doi.org/10.1016/..appdev.2005.08.003.

Nickerson, A. B., \& Nagle, R. J. (2005). Parent and peer attachment in late childhood and early adolescence. The Journal of Early Adolescence, 25(2), 223249. https://doi.org/10.1177/0272431604274174. 
Park, R. E. (1924). The concept of social distance as applied to the study of racial attitudes and racial relations. Journal of Applied Sociology, 8, 339-344.

Piaget, J. (1929). The child's conception of the world. London: Routledge \& K. Paul.

Piaget, J. (1960). The psychology of intelligence. Paterson: Littlefield, Adams. /zwcorg/.

Piaget, J., Cartalis, M. E., Hanhart, A., Hahnloser, L., Matthes, O., Perret, S., \& Roud, M. (1928). Judgement and reasoning in the child. Retrieved from https:// www.taylorfrancis.com/books/9780203207260

Pike, M. M., Barnes, M. A., \& Barron, R. W. (2010). The role of illustrations in children's inferential comprehension. Journal of Experimental Child Psychology, 105(3), 243-255. https://doi.org/10.1016/i.jecp.2009.10.006.

Powdermaker, H. (1944). The anthropological approach to the problem of modifying race attitudes. The Journal of Negro Education, 13(3), 295-302. https://doi.org/10.2307/2292447.

Raabe, T., \& Beelmann, A. (2011). Development of ethnic, racial, and national prejudice in childhood and adolescence: A multinational meta-analysis of age differences: Age differences in prejudice. Child Development, 82(6), 17151737. https://doi.org/10.1111/j.1467-8624.2011.01668.x.

Richardson, S. A., Goodman, N., Hastorf, A. H., \& Dornbusch, S. M. (1961). Cultural uniformity in reaction to physical disabilities. American Sociological Review, 26(2), 241. https://doi.org/10.2307/2089861.

Rustenbach, E. (2010). Sources of negative attitudes toward immigrants in Europe: A multi-level analysis. International Migration Review, 44(1), 53-77. https://doi.org/10.1111/j.1747-7379.2009.00798.x.

Savelkoul, M., Scheepers, P., van der Veld, W., \& Hagendoorn, L. (2012). Comparing levels of anti-Muslim attitudes across Western countries. Quality \& Quantity, 46(5), 1617-1624. https://doi.org/10.1007/s11135-011-9470-9.

Schafer, J. L., \& Graham, J. W. (2002). Missing data: Our view of the state of the art. Psychological Methods, 7(2), 147-177. https://doi.org/10.1037//1082-989X. 7.2.147.

Schupp, J., Goebel, J., Kroh, M., Schröder, C., Bartels, C., Erhardt, K., ... Deutsches Institut Für Wirtschaftsforschung (DIW Berlin). (2017). Socio-economic Panel (SOEP), Data for years 1984-2016 [Data set]. doi.https://doi.org/10.5684/soep.v33

Sutherland, P. A. A. (1992). Cognitive development today: Piaget and his critics. SAGE Publications.

Thurstone, L. L. (1931). The measurement of social attitudes. The Journal of Abnormal and Social Psychology, 26(3), 249-269. https://doi.org/10.1037/ h0070363.

Verkuyten, M. (2002). Ethnic attitudes among minority and majority children: The role of ethnic identification, peer group victimization and parents. Social Development, 11(4), 558-570. https://doi.org/10.1111/1467-9507.00215.

Williams, J. E., Best, D. L., Boswell, D. A., Mattson, L. A., \& Graves, D. J. (1975). Preschool Racial Attitude Measure II. Educational and Psychological Measurement, 35(1), 3-18. https://doi.org/10.1177/001316447503500101.

Zick, A., Wolf, C., Küpper, B., Davidov, E., Schmidt, P., \& Heitmeyer, W. (2008). The syndrome of group-focused enmity: The interrelation of prejudices tested with multiple cross-sectional and panel data. Journal of Social Issues, 64(2), 363-383. https://doi.org/10.1111/j.1540-4560.2008.00566.x.

\section{Publisher's Note}

Springer Nature remains neutral with regard to jurisdictional claims in published maps and institutional affiliations.

Ready to submit your research? Choose BMC and benefit from:

- fast, convenient online submission

- thorough peer review by experienced researchers in your field

- rapid publication on acceptance

- support for research data, including large and complex data types

- gold Open Access which fosters wider collaboration and increased citations

- maximum visibility for your research: over $100 \mathrm{M}$ website views per year

At BMC, research is always in progress.

Learn more biomedcentral.com/submissions 